\title{
PERFORMANCE CHARACTERISTICS OF A SLOTTED-CAGE SOLID ROTOR THREE-PHASE INDUCTION MOTOR WITH CONSTANT-VOLTAGE SOURCE (EXPERIMENTAL INVESTIGATION)

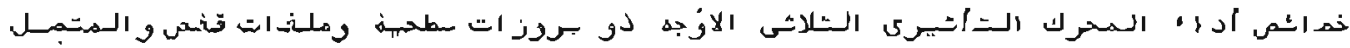

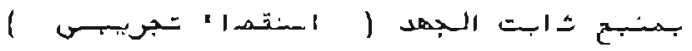

\section{A.R.A.AMIN M.M.I.EL-SHIAMMOTY S.A.EL-DRIENY \\ Electrical Englneering Department,}

Faculty or Engineering,

El-Mansoura Undversily, Ez-Mansoura, EGYPT

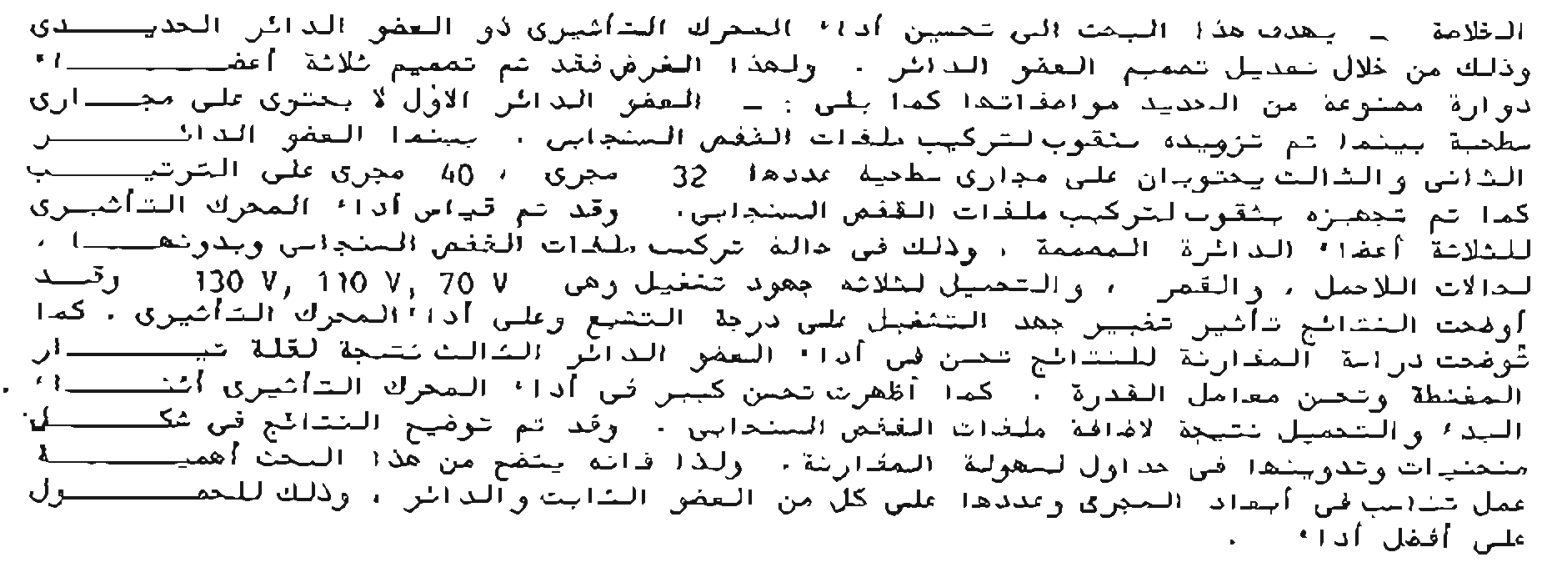

\section{ABSTRACT:}

The performance characteristics of a new form of a solid rotor, three-phase Induction motor has been investigated. For thls purpose, three differentiy slotted rotors were designed, and succegsively examined in the rotating fleld of a $36-s t a t o r$ siots. These rotors having noslot, 32-slot, and 40-slot. Comparing the performance of these rotors with and without cage winoling, brought out clearly the Influence of the various parameters that affect the performance of a slotted-cage induction motors. These parameters are the slot wlath, the slot depth, the slot numbers, and the saturation of the magnetic material.

It ls notlced that the performance characterlstlcs for 40 slotted-cage inaction motor have been improved corsiderably in comparison with the other two rotors. With this slotted-cage rotox the improvements are observed allover the torque/speed, and powerfactor/ speed characteristics. Thus, these Investigations enable optlmum design of the slotted-cage rotor for a glven stator frame. 


\section{INTRODUCTION:}

Interest has axdsen for many years in the operating characteristlcs of the solid rotor three-phase lnauction motor; notably with reference to starting and running performance. These motors show a useful reduction in the starting current, but the accompanded reduction in pexformance characteristics at rated voltage, owlng to the Inherent high reslstance, is generally unacceptable $13,2 \mathrm{l}$. In addition, these motor suffer from the disadvantage of low power-factor and hlgh slip when operating under full-load conditions. Technlques such as the fittlng of copper end plates 131 or the machining of deep radlal silts in the rotor sureace [4] were introduced for relieving these problems, but they do not present entlrely a satiafactory and practical solution.

Therefore, the authorg have guggested to Introouce the concept of the cage winding uith elther smoothed or toothed solid lron rotors. The cage winding has been Eltted into the solid iron rotor. guch configuration is denoted as a slotted cage rotor. The analygis of this conflguration from the fleld point of view is essentially a threeolmenslonal problem; where the presence of slots alters the solld rotor magnetic propertles, whlle the cage winding changes its electrlc properties. The fleld solution of the slotted-cage rotor conflguration congldering the effect of the slot depth, slot width, slot number, Einite rotor length, and the nonlinearity of the material is very complicatted. Therefore, in order to bring out clearly the effects of varlation in the physlcal dimenslons of the slots and thele numbers on the machine performance, three different rotors have been deslgned and tested. In addition, the gaturation effect has been consldered by recording the almed results at three levels of supply voltage; 70,110 , and 130 volt. Moreover, each of the three solld rotor has been equipped with a cage winding, in order to give an insight into its effect on the performance of the solid rotor Induction motor.

\section{THE SPECIFICATION OF THE RROROSED ROCOBS DESIGN:}

The relatively high reslstance of a solld iron rotor, compared with a laminated cage rotor, reduces the performance characterlatics at rated voltage. The performance of a solla rotor induction motor for these respects can be improved conslderably by lntroducing a conventional squirrel cage ulnding. Such slorted cage rotor may exhiblt a more advantageous variation of effective lmpedance during running operation. The behaviour of the proposed slotted-cage rotor differs conslderably as the terminal voltage varles. At reduced terminal valtage, the outer izon shell is designed to be of sultable thlckness to carry the flux as the slotted-cage cotor will exhiblt a solld rotor characteristics. However, at higher terminal voltages, the flux penetrates deeply into the inner surfaces and Ilnks with the squlxrel-cage winding. Therefore, the cage winding comes Into operation and the deslred reduced resistance is achleved. Accordingly, a better performance would be exhlbited by the slotted-cage rotor. 
To verffy these important knovledge three rotors are designed with different physical dimensions.to reveal the lnfluence of each of the slot depth, slot width, slot numbers on the machine performance. In addition, the effect of introducing the cage vinding into these rotors has been 1 lilutrated. A proto-type lnduction motor, rated at $1.5 \mathrm{kw}$, 4-pole., 36-stator slot, 3-ph, 450 turns pex phase, demonstrated the achievement of the oredicted performance with each soldd iron rotor. The rotors specifications are glven in table (ג).

Table (1)

The Proposed Rotorg speclelcations

\begin{tabular}{|c|c|c|c|}
\hline Name & $\begin{array}{l}\text { Rotor } \\
\text { No. } 1\end{array}$ & $\begin{array}{l}\text { Rotor } \\
\text { No. } 2\end{array}$ & $\begin{array}{l}\text { Rotor } \\
\text { No. } 3\end{array}$ \\
\hline Rotor Dlameter (D) & 104 & 104 & 104 \\
\hline$A \perp c$-gab Length & 0.3 & 0.3 & 0.3 \\
\hline Effective Rotor Length (L) & 54 & 54 & 54 \\
\hline Number of spaced slots (s) & 0 & 32 & 40 \\
\hline Depth of slots & 0 & 6 & 6 \\
\hline width of siots & 0 & 5 & 3 \\
\hline Hath of Teeth & 0 & 5.2 & 5.2 \\
\hline Mean Dlameter of End RIng & 89 & 68 & 68 \\
\hline End Rlng Thlckness & $\begin{array}{c}8.5 \\
\text { (copper) }\end{array}$ & $\begin{array}{c}8 \\
\text { (a) lum }\end{array}$ & $\begin{array}{c}8 \\
\ln 1 \text { un })\end{array}$ \\
\hline Number of Cage Bar & 12 & 12 & 12 \\
\hline Diameter of each Bar & 8 & 8 & 8 \\
\hline
\end{tabular}

All the dimensions are in millimelers.

\section{EXPERTMENTAL RESULTS AND DISCUSSION:}

Experlments were conducted to measure and to predict the pextormance characteristics of the three solid rotors inaction motor at strarting and running condltions. Load, no-load, and short-cirult tegts were carrled out almed at the measurment of the Input pover, and the input current and to predict lhe torque, and powtr-factor at varlaus soeeds for three levels of supply voltage. These results were glven for three different rotors elther equipped with cage winding arranged lnta the solid rotor, or with no cage winaing. The results of these tests, Fig. (1), have shown to be vaxied conslderably with a supply voltage and the type of the solld rotor conflguration under test. These results have brought out cleaxly the influence of introducing the cage winding into the three designed rotorg. The presence of the glots in the solid rotorg is shown to lmprove the machlne performance. However, the presence of the cage ulnding in the solid rotors is shown to have a slgnificant influence allover the motor performance.

A comparltive study of the no-road, and short clrcult test results presented for the three solla rotors were ligted in Tables (2) to (4). These Tables contain and introduce the particular interesting values at starting and runing light conditions for three levels of supply 

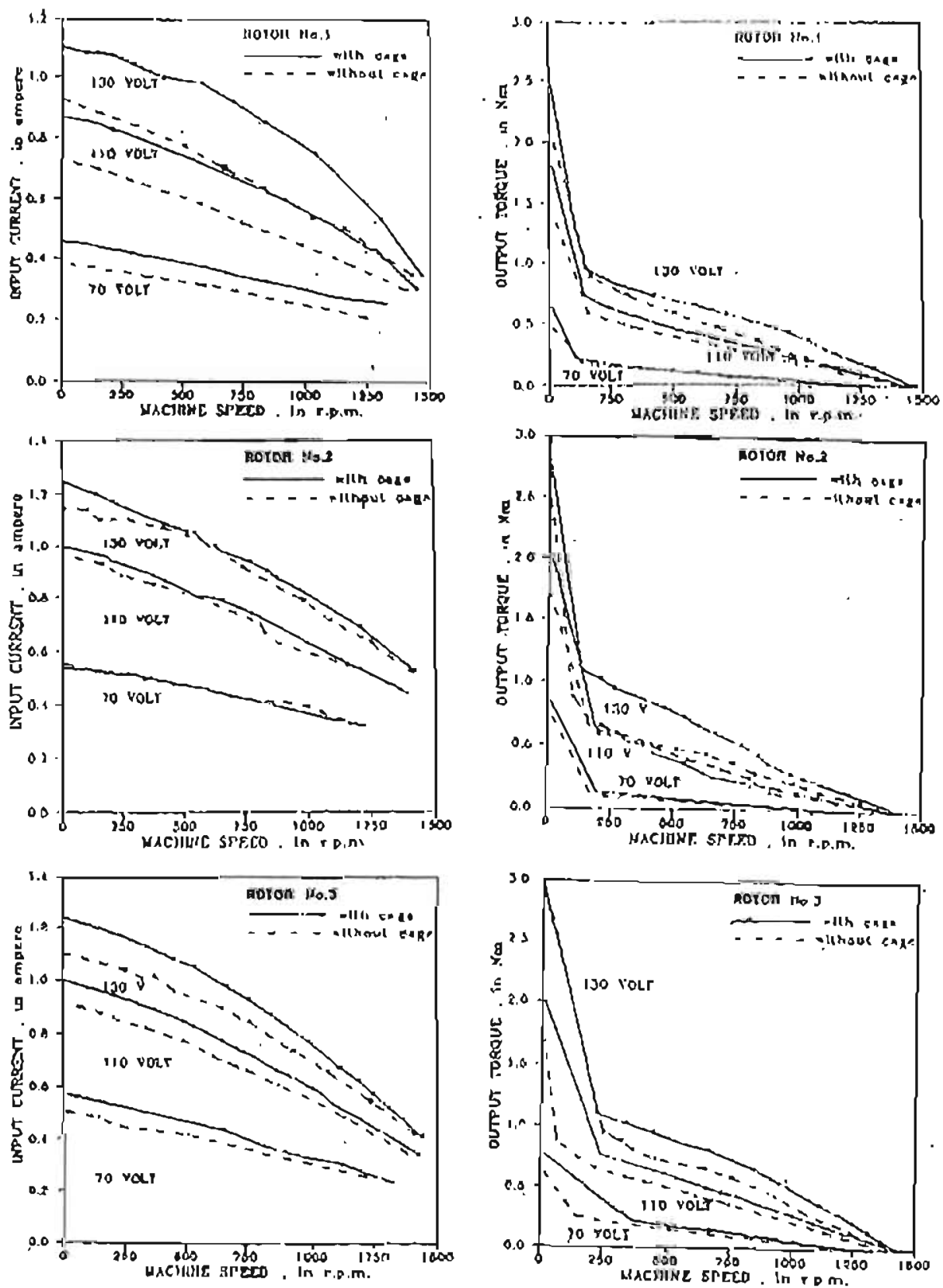

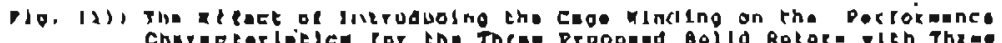

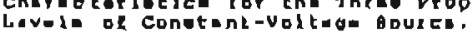



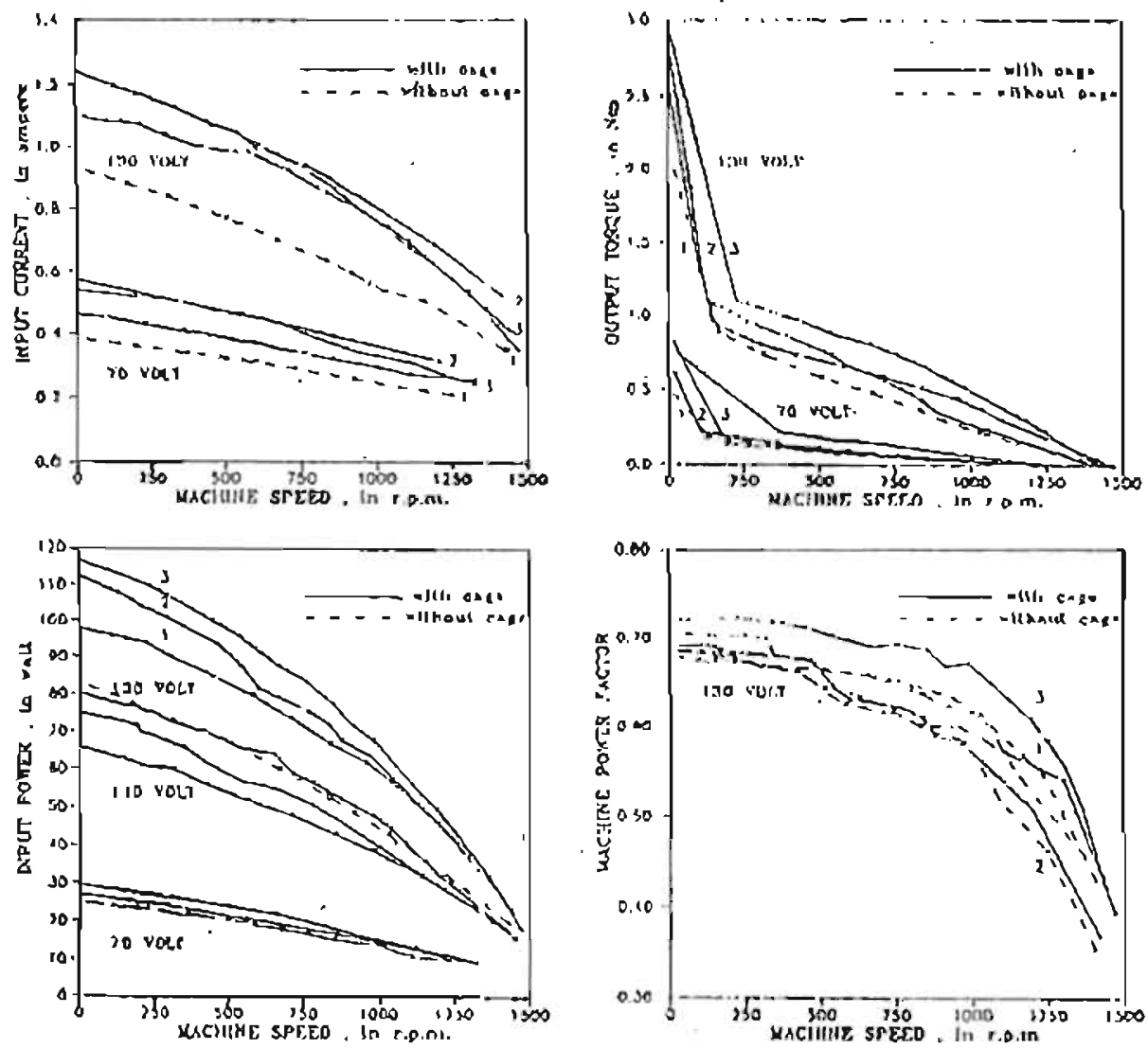

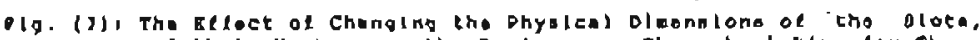

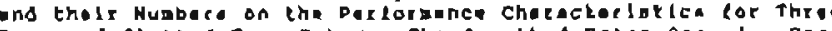
proposed slotted-cinge 
voltage; 70,120 , and 130 volt. It is shown that, from locked rotor tests at three constant-voltage sources, introducing the axlal slots in a solid rotor, increases the pexlphery path of the eday current (5), thereby markedly reducling the effectlve resistance and reactance. consequently, the machine whil exilbit mare reduction in thelr effective resistance and reactance, when elther the smoothed or slotted rotor is equipped with cage winding. Accordingly, a high power-factor is obtalned, with high voltage, especially with rotor No. 3. On the other hand, at reduced voltage, the power-factor for the unslotted rotor was high. However, it has been noticed that, with the nom load test, slotting the ixon rotors Implies an imcreases in magnetlsing current. Where, rotor No. 2 with wide slots almensions, requlres an incxease in magnetising current in comparlson with rotor No. 3, since the wide slot rotors require a definite value of magnetislng force to drive the flux tirrough the teeth due to the increasing in radial flux density. Furthermore, the presence of slotting in the rotor itself increases the effective alr-gap which also requires additional magnetising ampere-turns. Tables 2 to 4 111 ustate all the phenomena, whlch have been explalned.

A compartive study of the load test results presented in Fig. (2) reveals that, the performance of the $32-5$ lot machine was intermediate between the smoothed rotor and $40 \sim 5$ lot one. Moreover, experimental evidence shows a varlation of the pover-kactor with speed, this varlation being large at very low sllp. In addition, a slgnificant improvement on the performance characteristics with a cage winding la revealea.

Furthermore, this investlgatlon indicates the lneluence of reducing the slot wlath, with malntalning the teeth physical oimensions constant. Thus these investigation enables optimum design of the solla lron rotor for a glven stator frame.

Table $(2)$

the No-load and short-clrcult Results at supply voltage/ph $=70$ volt.

\begin{tabular}{|c|c|c|c|c|c|c|}
\hline & Rotor $\mathrm{N}$ & . 1 & Rotor & . 2 & Rotor & No. 3 \\
\hline & $\begin{array}{c}\text { wh thout } \\
\text { cage }\end{array}$ & $\begin{array}{l}\text { with } \\
\text { cage }\end{array}$ & $\begin{array}{c}\text { Without } \\
\text { cage }\end{array}$ & $\begin{array}{l}\text { with } \\
\text { cage }\end{array}$ & $\begin{array}{c}\text { without } \\
\text { cage }\end{array}$ & $\begin{array}{l}\text { with } \\
\text { cage }\end{array}$ \\
\hline silp at no-load & 0.167 & 0.117 & 0.187 & 0.193 & 0.187 & 0.117 \\
\hline N.L. current & 0.210 & 0.255 & 0.320 & 0.317 & 0.263 & 0.240 \\
\hline s.c. current & 0.385 & 0.460 & 0.555 & 0.540 & 0.510 & 0.575 \\
\hline N.L. power factor & 0.629 & 0.532 & 0.547 & 0.507 & 0.597 & 0.565 \\
\hline S.C. power factor & 0.723 & 0.777 & 0.69 & 0.719 & 0.728 & 0.733 \\
\hline staxting toxque $\{\mathrm{Nm}\}$ & 0.515 & 0.698 & 0.787 & 0.883 & 0.760 & 0.890 \\
\hline s.c. reactance & 125.500 & 95.820 & 91.310 & 90.230 & 94.060 & 82.830 \\
\hline S.C. resistance & 131.560 & 118.220 & 87.01 & 92.590 & 99.96 & 89.220 \\
\hline
\end{tabular}


Taple $(3)$

The No-load and Short-cixcuit Results at supply Voltage/ph $=110$ volt.

\begin{tabular}{|c|c|c|c|c|c|c|c|c|}
\hline \multirow{2}{*}{\multicolumn{2}{|c|}{$\cdot$}} & \multicolumn{3}{|c|}{ Rotor No. 1} & \multicolumn{2}{|c|}{ Rotor No. 2} & \multicolumn{2}{|c|}{ Rotor No. 3} \\
\hline & & $\begin{array}{c}\text { Whout } \\
\text { cage }\end{array}$ & & $\begin{array}{l}\text { With } \\
\text { cage }\end{array}$ & $\begin{array}{c}\text { W thout } \\
\text { cage }\end{array}$ & $\begin{array}{l}\text { with } \\
\text { cage }\end{array}$ & $\begin{array}{c}\text { without } \\
\text { cage }\end{array}$ & $\begin{array}{l}\text { with } \\
\text { cage }\end{array}$ \\
\hline$\overline{S \perp 1 P}$ & at no-10ad & 0.060 & & 0.033 & 0.077 & 0.083 & 0.077 & 0.053 \\
\hline $\begin{array}{l}\text { N.L. } \\
\text { S.C. } \\
\text { N.L. } \\
\text { S.C. } \\
\text { Start } \\
\text { S.C. } \\
\text { S.C. }\end{array}$ & $\begin{array}{l}\text { current } \\
\text { current } \\
\text { power factor } \\
\text { power factor } \\
\text { ting torgue ( } \mathrm{Nm}) \\
\text { reactance } \\
\text { resistance }\end{array}$ & $\begin{array}{r}0.300 \\
0.730 \\
0.485 \\
0.697 \\
1.520 \\
108.000 \\
105.080\end{array}$ & $\begin{array}{l}0 \\
0 \\
0 \\
0 \\
1 \\
91 \\
87\end{array}$ & $\begin{array}{l}0.505 \\
0.870 \\
0.476 \\
0.689 \\
.912 \\
.560 \\
.200\end{array}$ & $\begin{array}{r}0.440 \\
0.970 \\
0.413 \\
0.656 \\
1.760 \\
85.580 \\
74.400\end{array}$ & $\begin{array}{r}0.450 \\
1.000 \\
0.404 \\
0.682 \\
2.130 \\
80.470 \\
75.000\end{array}$ & $\begin{array}{r}0.352 \\
0.920 \\
0.490 \\
0.697 \\
1.830 \\
86.340 \\
76.090\end{array}$ & $\begin{array}{r}0.350 \\
1.000 \\
0.468 \\
0.730 \\
2.160 \\
75.180 \\
80.300\end{array}$ \\
\hline
\end{tabular}

Takle $|4\rangle$

The No-load and Short-clrcult Results at supply voltage/ph $=130$ valt.

\begin{tabular}{|c|c|c|c|c|c|c|}
\hline & Rotor $N$ & vo. 1 & Rotor & so. 2 & Rotor & o. 3 \\
\hline & $\begin{array}{c}\text { Without } \\
\text { cage }\end{array}$ & $\begin{array}{l}\text { with } \\
\text { caqc }\end{array}$ & $\begin{array}{c}\text { without } \\
\text { cage }\end{array}$ & $\begin{array}{l}\text { with } \\
\text { cage }\end{array}$ & $\begin{array}{c}\text { Whaut } \\
\text { cage }\end{array}$ & $\begin{array}{l}\text { wlth } \\
\text { cage }\end{array}$ \\
\hline sl1p at no-load & 0.048 & 0.020 & $0 . \overline{063}$ & 0.053 & 0.060 & 0.040 \\
\hline N.L. current & 0.352 & 0.350 & 0.520 & 0.525 & 0.430 & 0.417 \\
\hline S.c. current & 0.930 & 1.100 & 1.150 & 1.250 & 1.100 & 1.240 \\
\hline iv. L. power factor & 0.437 & 0.395 & 0.355 & 0.370 & 0.430 & 0.429 \\
\hline S.c. power factor & 0.676 & 0.679 & 0.679 & 0.692 & 0.705 & 0.724 \\
\hline starting torgue (Nm) & 2.133 & 2.570 & 2.660 & 2.870 & 2.900 & 2.990 \\
\hline S.C. reactance & 101.640 & 86.060 & 83.000 & 75.050 & 83.820 & 22.320 \\
\hline s.c. reslstance & 95.970 & 81.000 & 76.750 & 72.000 & 83.310 & 75.900 \\
\hline
\end{tabular}

\section{CONCLUSION:-}

This paper brlngs out the effects of varying the physlcal dimension of the slotted rotor, as well as the effect of lncluding cage winding into the rotors on the machine pexformance; through an experimental investigation. A comparative study of the test results leads to some interesting conclusions.

1) It is established that the provision of axlal slot on the rotor has a conslderable influence on the performance characterlstics. Moreover, the cage winding presents a further reduction in the rotor impedance and the current/speed and torque/speed curves exhibit steeper characteristics for the same applled voltage. 
2) As the rotar-tooth dimension is kept canstant, the magnetising current requlred by a wider dimensions of the slotted rotor Increases. Where the effective alr gap for such rotor is increased. Accordingly, the power-factor for thls cage is lower than that of the smootined solld rotor at low slips, but lmproves ulth increasing sllps. The addition of the cage winding to the rotor provides a considerable improvement in the pover-factor; especialiy with rotor No. 3 .

3) It 19 notlced that, there is a fucther reduction in the glip with the rotors equipped with a squirrel cage winding; especiajly with the smoothed rotor as the mechanlcal frjction ls very gnall.

4) Fingliy, a better performance characterlstics of the solid rotor ls cotalned by Increasing the periphery path of the edoy current. Therefore, Increasing the glot depth is recommended with high number of slots. Moreover, a signjflcant lmprovement on the machlne performance is revealed when the cage ulnding comes into effect. Therefore, a compromise between the number of slots, slot width, s)ot depth, and the cage winding becoms essentlal for optimum design.

\section{REEERENGES:}

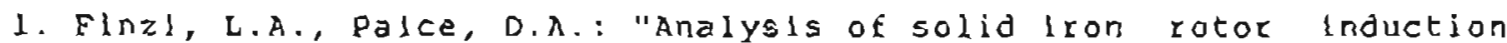
motor for solidastate speed controls", IEeE Trans., pas-87, pp. $590-596,1968$.

2. Chalmers, B.J., Herman J.: "Inouction motor fan orlve with unlaminated rotor and heat-plpe cooling", Proc. IEE, 124, (5), pp. $449-453,1977$.

3. Woolley, I., Chalmers, B.J.: "End effects in uniaminated-rotor induction machlnes", ibja, 120, (6), pp. 641-646, 1973.

4. Dorajxaj, K.R., Krlsmnamurthy, M.R.: "Poly-phase inductlon machine whth a slitted ferromagnetic rotor. Pt. 2-analysls", reee trans.. PAS-96, P. 844-855, 1967.

5. Rajagocalan, P.K., Badaramamurty, V, , Sarma, P.S.: "Tooth-Elux distribution in slotted solid iron rotor", Proc. IEE, vol. 217, No. 1. PO. $101-108,1970$. 